\title{
THE ANALYSIS OF TEACHER AND STUDENTS TALK IN INDONESIAN EFL CLASSROOM INTERACTION
}

\author{
Shilvia Nur Meida \\ Department of English Education, Faculty of Teachers Training and Education, University of Kuningan, \\ Indonesia \\ E-mail: shilvianurmeida@gmail.com \\ Fahrus Zaman Fadhly \\ Department of English Education, Faculty of Teachers Training and Education, University of Kuningan, \\ Indonesia \\ E-mail: fahruszf@uniku.ac.id
}

APA Citation: Meida, S. N., \& Fadhly, F. Z. (2018). The analysis of teacher and students talk in indonesian EFL classroom interaction. Indonesian EFL Journal, 4(1), 73-82. DOI: 10.25134/ieflj.v4i1.886.

Published: 01-01-2018

\begin{abstract}
This research analyzes teacher and students talk in Indonesian EFL classroom interaction in University of Kuningan in second semester who are taking Speaking 2 subject. This qualitative data was from observation, note taking, and interview. The result of classroom observation found the content cross as the most dominant characteristic in teacher and students talk, it means that most of the teaching learning process devoted to asking questions and lecturing by the lecturer. The proportation of content cross was $65.55 \%$ in the first meeting, $95.88 \%$ in the second meeting, and $97.44 \%$ in the third meeting. While, in the additional data, the most dominant category found was teacher talk. It means that all of teacher talk categories appear in each meeting. The proportation of teacher talk is $38.16 \%$ in the first meeting, $55.11 \%$ in the second meeting, and $54.83 \%$ in the third meeting. In addition, the result of note taking and interview indicated that the interaction always happened in teaching learning process among students although the lecturer's role is still dominant.
\end{abstract}

Keywords: teacher and students talk, FIAC analysis system, speaking skill

\section{INTRODUCTION}

Teaching is the activity of organizing student activities and providing good learning facilities so that students can learn well. In contrast, learning is the activity of increasing students' knowledge about the lesson which is done by teacher. In teaching and learning process in the classroom, there is always an interaction between teacher and students. In classroom interaction, teacher and students have to make a good communication in order to make students understand the materials being taught. As Brown (2001, p. 165) says, “....interactionis, in fact, the heart of communication: it is what communication is all about."

Similarly, Dagarin (2004, p. 128) argues that classroom interaction is "two way process between the participants in the language process, the teacher influences the learners and vice versa." In Indonesia, English as EFL (English as Foreign Language) is still difficult to be used especially in applying it into interaction during English speaking classroom. It is happened since the EFL students have common native languages (Brown, 2001, p. 180). Besides, Brown (2001, p. 116) also states that foreign language context are those in which students do not have ready-made contexts for communication beyond their classroom. EFL (English as a Foreign Language) context is a greater challenge for the students. The need for English speaking mastery has increased due to the status of English as a global language which is recognized in every country (Crystal, 2003, p. 3). Hence, the students who study English have to master it well, so the goal of 
English teaching and learning process could be achieved.

From the statement above, the problem of interaction in the classroom especially in English speaking classroom can be solved if the teacher teaches their students for mastering English well and good in communication with their classmates. The students have to realize that doing interaction in language classroom is very important. As Rivers (1987, p. 4) states "interaction plays significant roles in the language classroom since it can increase students' language store." Further, the interaction in the language classroom has profits to the students' ability and achievement in speaking.

This research identifies the categories of teacher and students talk appeared in Indonesian EFL classroom interaction. Ideally, the students can be more active than teacher and they can do good interaction in the classroom. If in the teaching-learning process the teacher talk too much, it will cause the students cannot speak up freely. This study is conducted because today the students should be the centre of the learning process. Student-centred learning, as the term suggests, is a method of learning or teaching that puts the learner at the centre (MacHemer et al, 2007, p. 9; Boyer, 1990).

Flanders (1970) as cited in Arockiasamy (2012) classifies verbal behavior into three categories; 1) teacher talk consisting of indirect talk (accepting feelings, praise or encouragement, accepting or using ideas of students, asking questions) and direct talk (lecturing/lecture, giving directions, criticizing or justifying authority); 2) Students talk consisting of two categories, including student talk response (response to teacher' talk) and student talk initiation (Expressing own ideas, initiating a new topic, freedom to develop opinions, etc.); and 3) silence or pauses or confusion.

Based on the description above, this research is conducted to find out the teacher and students talk categories appeared in Indonesian EFL classroom interaction, and to find out the most dominant category of the teacher and students talk categories that appear in Indonesian EFL classroom interaction.

\section{METHOD}

This descriptive qualitative research undertook at Department of English Education of the University of Kuningan. The participants who involved in this research were the students who were taking the Speaking 2 subject in second semester, especially the students in class $1 \mathrm{~A}$ (consisting of 23 students). The data were then collected through observation, note taking and interview. Furthermore, to investigate the talk of teacher and students in the classroom interaction, this research employed FIAC (Flanders Interaction Analysis Categories) analysis system by Flanders (1970).

The data would be then analyzed by using the four steps of FIAC analysis system, as follows.

Step 1: Coding the verbal interaction, the observer translates the observed behavior into a descriptive code. Each verbal behavior is recorded as a number of categories, for example:

\begin{tabular}{lc}
\hline Actual Classroom Verbal Interaction & Recorded as category \\
\hline Teacher : What's the color of a banana? & 4 \\
Students : Yellow. & 8 \\
Teacher : Yes, right! & 2 \\
The color is yellow. & \\
\hline
\end{tabular}

Step 2: Plotting the coded data into the matrix, to plot the numbers recorded, for example an observation recorded is 6, 5, 7 . Hence, the beginning and end of the coding should have the same number of the categories. It is the tradition of adding number
10 in the beginning and at the end. Hence, the number will be written in this way $10,6,5,7$, 10 . The writer conducted plotting the coded data into the matrix, for example the table below. 


\begin{tabular}{lll}
\hline & $\mathbf{1 0}$ & \\
\cline { 1 - 2 } & 6 & \\
& 5 & \\
& $2^{\text {nd }}$ pair \\
$3^{\text {rd }}$ pair & 7 & \\
& 10 & \\
& $4^{\text {th }}$ pair \\
\hline
\end{tabular}

Sequence of the pair: $(10,6),(6,5),(5,7),(7$, $10)$. The matrix consists of ten rows and ten columns. The first number of the pair represents 'row' and second number of the pair represents 'column'. For example, in the first pair $(10,6)$, the number 10 represents row and the number 6 represents column. Every pair overlaps the other pair. Total tallies of the matrix $(\mathrm{N})$. Below is the sample matrix of the Flanders' coding system.

\begin{tabular}{cccccccccccc}
\hline row & 1 & 2 & 3 & 4 & 5 & 6 & 7 & 8 & 9 & 10 & Total \\
\hline 2 & & & & & & & & & & & 0 \\
3 & & & & & & & & & & & 0 \\
4 & & & & & & & & & & & 0 \\
5 & & & & & & & & & & & 0 \\
6 & & & & & 1 & & & & & & 1 \\
7 & & & & & & & & & & & 1 \\
8 & & & & & & & & & & & 1 \\
9 & & & & & & & & & & & 0 \\
10 & & & & & & $/$ & & & & & 0 \\
Total & 0 & 0 & 0 & 0 & 1 & 1 & 1 & 0 & 0 & 1 & $4(\mathrm{~N})$ \\
\hline
\end{tabular}

Step 3: Analyzing the matrix, in a complete matrix, some areas have tallies than others. A heavier concentration of tallies in a certain area gives information about who is talking and what kind of talking is taking place. Below is the example

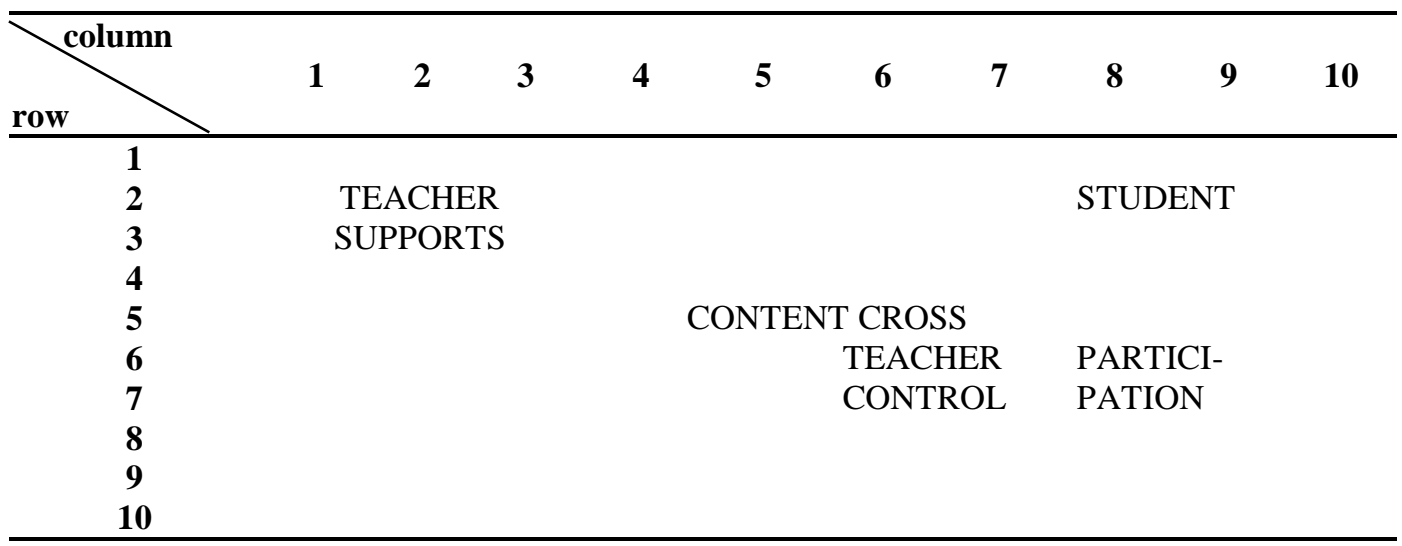

1. Content Cross: a heavy concentration in a column 4 and 5 and row 4 and 5 indicates teacher dependence on questions and lectures.
2. Teacher Control: a concentration on column and row 6 and 7 indicates extensive commands and reprimands by the teacher. 
3. Teacher Support: a heavy concentration of tallies in column and row 1, 2, and 3 indicates that the teacher is reinforcing and encouraging students' participation.

4. Student Participation: a concentration of tallies in column 8 and 9 reflects student responses to the teacher's behavior.

Step 4: Analyzing the additional data, as follows: Teacher' Talk, Lecturing, Direct

\begin{tabular}{|l|l|l|l|l|l|l|l|l|l|l|}
\hline Columns & 1 & 2 & 3 & 4 & 5 & 6 & 7 & 8 & 9 & 10 \\
\hline Total numbers & 4 & 8 & 5 & 10 & 5 & 9 & 6 & 7 & 6 & 20 \\
\hline
\end{tabular}

Total for all columns : 80

Total for column $10: 20$

Proportion of classroom time spent silent:

$$
\begin{aligned}
\frac{\text { Column } 10}{\text { Column 1-10 }} & =\frac{20}{4+8+5+10+5+9+6+7+6+20} \\
& =\frac{20}{80} \times 100 \\
& =25 \%
\end{aligned}
$$

\section{RESULTS AND DISCUSSION}

Based on the three meeting that have been conducted at the Speaking subject of second semester of English Department in the University of Kuningan, it was found that all categories in teacher talk, studets talk, and silent or confusion had been applied by the subjects.

\section{The result of the first meeting}

In the first meeting on April, 29 2015, almost all categories of Flanders Interaction Analysis Categories (FIAC) analysis system appeared in classroom interaction. Yet, one category which did not appear in this meeting is the $7^{\text {th }}$ category; Criticizing or Justifying Authority. Based on the result of step 3 of the previous part in the first meeting, the most dominant characteristic of categories found was the content cross which consisted of $4^{\text {th }}$ and $5^{\text {th }}$ category, that are two of the teacher talk categories. The proportion of content cross in the first meeting was $65.55 \%$ showing that the lecturer spent more time in teaching learning process for asking questions and lecturing. The lecturer still spent more time than the students. The proportion of content cross in this meeting was the lowest one compared to the second and the third meeting.
Teaching, Indirect Teaching, and Silent. Adding the tallies in any column and comparing that number to the tallies in other columns can determine the percentage of time spent on that activity. For example, adding up all the tallies in column 10 and comparing that number to tallies in the other columns on the matrix will show how much classroom time the teacher and students in silent. For example: 
and accepting students's ideas. The proportion of teacher support in this meeting was lower than the second meeting but it was higher than the third meeting.

From the additional data based on step 4 in data presentation, the other characteristics of classroom interaction could be analyzed. The characteristics of classroom interaction in the first meeting are summarized below.

1. The most dominant characteristic of the additional data was teacher talk which consisted of all teacher talk categories from the $1^{\text {st }}-7^{\text {th }}$ category. The proportion of teacher talk in the first meeting was $38.16 \%$ meaning that the lecturer still dominated the classroom interaction. The proportion of teacher talk in this meeting the lowest one compared to the second and the third meeting.

2. The second dominant characteristic of the additional data was direct teaching which consisted of the $5^{\text {th }}, 6^{\text {th }}$, and $7^{\text {th }}$ category. It spent $25.22 \%$ meaning that the lecturer spent more time in direct teaching to her students (lecturing, giving directions, and criticizing or justifying authority). The proportion of direct teaching in this meeting the lowest one compared to the second and the third meeting.

3. The third dominant characteristic of the additional data was lecturing $\left(5^{\text {th }}\right.$ categoty), it is one of the teacher talk categories. It spent $21.88 \%$ meaning that the lecturer was giving facts or opinions about content or procedure expression of her own ideas, giving her own explanation or citing an authority other than students. The proportion of lecturing in this meeting was the lowest one compared to the second and the third meeting.

While in indirect teaching $\left(1^{\text {st }}\right.$ and $4^{\text {th }}$ category) that are some categories of teacher talk. Lecturer spent $12.94 \%$ in indirect teaching in the first meeting. It was the highest compared to the second and the third meeting. Furthermore, in silent or confusion $\left(10^{\text {th }}\right.$ category) the classroom spent $1.16 \%$ in the first meeting. It means that there is still silent or no interaction between lecturer and students and it was the lowest one compared to the second and the third meeting.

\section{The result of the second meeting}

In the second meeting on May, 6 2015, almost all categories of Flanders Interaction Analysis Categories (FIAC) analysis system appeared in classroom interaction. Yet, one category which did not appear in this meeting was the $7^{\text {th }}$ category; Criticizing or Justifying Authority. It is one of the teacher talk categories. Based on the result of step 3 of the previous part in the second meeting, the most dominant characteristic of categories found was the content cross which consisted of the $4^{\text {th }}$ and $5^{\text {th }}$ category, that are two of the teacher talk categories. The proportion of content cross in the second meeting was $95.88 \%$, showing that the lecturer spent more time in teaching learning process for asking questions and lecturing. The lecturer dominanted the classroom activities and it was higher than the first meeting but it was lower than the third meeting.

The second dominant characteristic was the students' participation or can also be called as the student talk which consisted of the $8^{\text {th }}$ and $9^{\text {th }}$ category, that are the categories of student talk. The students participated in responding the teacher's question and talking initiation. The proportion of student's participation in the second meeting was $35.55 \%$ meaning that the students were active enough in the classroom interaction. The students's participation in the classroom activities was still high but it was the lowest compared to the first and the third meeting.

The third dominant characteristic was the teacher support which consisted of the $1^{\text {st }}$, $2^{\text {nd }}$, and $3^{\text {rd }}$ category, that are three of teacher talk categories. It spent $11 \%$ of teaching learning process in the second meeting. It showed that the teacher was rarely in accepting feeling, praise or encouragement and accepting students' ideas. The lecturer's role in supporting the students in the classroom activities was the highest one compared to the first and the third meeting. While in teacher control which consisted of $6^{\text {th }}$ and $7^{\text {th }}$ category, that are two of teacher talk categories. Lecturer only spent $3.33 \%$ of the teaching learning process in the second meeting. It showed that the teacher spent a little time in giving directions and criticizing 
or justifying activity. The time of teacher control in the classroom activities was the lowest one compared to the first and the third meeting.

From the additional data based on step 4 in data presentation, the other characteristics of classroom interaction could be analyzed. The characteristics of classroom interaction in the second meeting are summarized below.

1. The most dominant characteristic of the additional data was teacher talk which consisted of all teacher talk categories from $1^{\text {st }}-7^{\text {th }}$ category. The proportion of teacher talk in the second meeting was $55.11 \%$ meaning that the lecturer still dominated classroom interaction and it was the highest one compared to the first meeting and the third meeting.

2. The second dominant characteristic of the additional data was direct teaching which consisted of the $5^{\text {th }}, 6^{\text {th }}$, and $7^{\text {th }}$ category. It spent $43.16 \%$ meaning that the lecturer spent more time in direct teaching to her students (lecturing, giving directions, and criticizing or justifying authority). In the second meeting, the lecturer's direct teaching was higher than the first meeting but it was lower than the third meeting.

3. The third dominant characteristic of the additional data was lecturing $\left(5^{\text {th }}\right.$ categoty), it is one of the teacher talk categories. It spent $41.5 \%$ meaning that the lecturer was giving facts or opinions about content or procedure expression of her own ideas, giving her own explanation or citing an authority other than students. In the second meeting, lecturing was higher than the first meeting but it was lower than the third meeting.

While in indirect teaching $\left(1^{\text {st }}\right.$ and $4^{\text {th }}$ category) there are some categories of teacher talk. Lecturer spent $11.94 \%$ in indirect teaching in the second meeting. It means that lecturer still spent much time in indirect teaching but it was lower than the first meeting and it was higher than the third meeting. Furthermore, in silent or confusion $\left(10^{\text {th }}\right.$ category), the classroom spent $9.33 \%$ in the second meeting. It means that there is still silent or no interaction between lecturer and students in this meeting and it was the highest one compared to the first and the third meeting.

\section{The result of the third meeting}

In the third meeting on May, 132015 , almost all categories of Flanders Interaction Analysis Categories (FIAC) analysis system appeared in classroom interaction. Yet, one category which did not appear in this meeting is the $2^{\text {nd }}$ category; Praise or Encouragement. It is one of the teacher talk categories. Based on the result of step 3 of the previous part in the third meeting, the most dominant characteristic of categories found was the content cross which consisted of the $4^{\text {th }}$ and $5^{\text {th }}$ category, that are two of the teacher talk categories. The proportion of content cross in the third meeting was $97.44 \%$, showing that the lecturer spent more time in teaching learning process for asking questions and lecturing. The lecturer dominated the classroom activities and it was the highest one compared to the first and the second meeting.

The second dominant characteristic was the students' participation or can also be called as student talk which consisted of the $8^{\text {th }}$ and $9^{\text {th }}$ category, that are the categories of student talk. The students participated in responding the teacher's question and talking initiation. The proportion of student's participationin in the third meeting was $36.17 \%$ meaning that the students were active enough in the classroom interaction. The students' participation in the classroom activities was still high but it was lower than the first meeting and it was higher than the second meeting.

The third dominant characteristic was the teacher control which consisted of the $6^{\text {th }}$ and $7^{\text {th }}$ category, that are two of teacher talk categories. It spent $8.66 \%$ of teaching learning process in the third meeting. It showed that the teacher spent a little time in giving directions and criticizing or justifying activity. In the third meeting, spent time in teacher control was highest than the first and the second meeting. While in teacher support which consisted of the $1^{\text {st }}, 2^{\text {nd }}$, and $3^{\text {rd }}$ category, there are three teacher talk categories in which the lecturer only spent $3.55 \%$ of the teaching learning process in the third meeting. It 
showed that the teacher was rarely in accepting feeling, praise or encouragement and accepting the students' ideas. In this meeting, the lecturer's support to her students was the lowest one compared to the first and the second meeting.

From the additional data based on step 4 in data presentation, the other characteristics of classroom interaction could be analyzed. The characteristics of classroom interaction in the third meeting are summarized below.

1. The most dominant characteristic of the additional data was teacher talk which consisted of all teacher talk categories from the $1^{\text {st }}-7^{\text {th }}$ category. The proportion of teacher talk in the third meeting was $54.83 \%$ meaning that the lecturer still dominated classroom interaction but it was higher than the first meeting and it was lower than the second meeting.

2. The second dominant characteristic of the additional data was direct teaching which consisted of the $5^{\text {th }}, 6^{\text {th }}$, and $7^{\text {th }}$ category. It spent $47.05 \%$ meaning that the lecturer spent more time in direct teaching to her students (lecturing, giving directions, and criticizing or justifying authority). In the third meeting, the lecturer's direct teaching was the highest one compared to the first and the second meeting.

3. The third dominant characteristic of the additional data was lecturing $\left(5^{\text {th }}\right.$ categoty), it is one of the teacher talk categories. It spent $42.72 \%$ meaning that the lecturer was giving facts or opinions about content or procedure expression of her own ideas, giving her own explanation or citing an authority other than students. In the third meeting, the lecturing was the highest one compared to the first and the second meeting.

While in silent or confusion $\left(10^{\text {th }}\right.$ category) spent $9 \%$ in the third meeting. It means that there was still silent or no interaction between lecturer and students in this meeting and it was higher than the first meeting but it was lower than the second meeting. Furthermore, in indirect teaching $\left(1^{\text {st }}\right.$ and $4^{\text {th }}$ category) there are some categories of teacher talk. Lecturer spent $7.77 \%$ in indirect teaching in the third meeting. It means that the lecturer still spent time in indirect teaching but it was lower than the first and the second meeting.

\section{The result of note taking}

There is the interaction between lecturer and students in the classroom activity. In the first meeting, the students spent more time than the lecturer in expressing their own ideas, their initiating, and their opinion in the classroom interaction and the lecturer was active enough in classroom interaction but the percentage of teacher talk was dominated by the students. Yet, in the second and the third meeting, the lecturer spent more time in giving facts or opinions, giving her own explanation or citing an authority other than students. Then, the students was also active enough in classroom interaction in expressing their own ideas, initiating and opinion, but the percentage of talk was more dominated by the lecturer. Furthermore, there was silent or confusion in the classroom interaction in each meeting although the percentage was low.

\section{The result of interview}

Based on the twelve questions of interview that the researcher was submitted to the interviewee, the researcher could be interpreted the result of interview as follows.

1. There is an interaction between the lecturer and the students in the classroom. Without the interaction, the process of teaching and learning cannot work well and the material of the subject cannot be delivered to students. So, it can be concluded that the interaction in the classroom has important role in the teaching and learning process.

2. The lecturer is able to distinguish which students who are exited or not in teaching and learning process, because the lecturer could see their facial expression. She also could feel the students's desire in learning the material.

3. The lecturer praises the students who can answer her questions relating to the material in the classroom. That praises became the reward to the students in order to increase students' spirit and desire in learning the material in the classroom. 
4. The lecturer repeated students' answer with her own words. It was done to make the other students understand about the student' answer since the lecturer's talk usually could be more understood than the students' words.

5. The lecturer always asked the students in the teaching learning process about the material that had been learned. It was because the lecturer wanted to the students' understanding about the material.

6. The lecturer always gave the fact and her opinion about the material in classroom. Usually, that fact and opinion based on the theory from the experts, books, and her experience.

7. In the classroom, the lecturer always gave the direction and instruction to the students in the teaching learning process. The lecturer usually gave direction and instruction related to the material learned.

8. The lecturer corrects or adds the students' answer. Yet, that was related to the students' answer itself and that activity was done rarely by the lecturer.

9. The students always gave the response to the lecturer when the lecturer asked them. Because if the students did not respond, the interaction in the classroom would not be work well and the teaching and learning process will not be effective.

10. The students always gave their ideas and opinion about the material in the classroom. Usually, they expressed their ideas and opinion about the material because the lecturer always asked them. Yet, some students usually gave their ideas or opinion without being asked. They expressed their ideas or opinion because they were very enthusiastic in the teaching process learning process.

11. In the teaching learning process, sometimes, there is no interaction occurred between all participants in the classroom and between the lecturer and the students.

12. The students are always given the time to conveyed their ideas or opinion about the material. It was done to make the students more active in the classroom.

\section{CONCLUSION}

In each meeting of Speaking 2 subject, almost all of the categories of FIAC system appear. There are teacher talk, students talk, and silent or confusion. But, there are two categories which does not appear; the $7^{\text {th }}$ category (Criticizing or Justifying Authority) in the first and the second meeting and the $2^{\text {nd }}$ category (Praise or Encouragement) in the third meeting.

The most dominant characteristic in Speaking 2 subject class was content cross. It means that the category that mostly appear are the $4^{\text {th }}$ (asking questions) and the $5^{\text {th }}$ (lecturing or lecture) category of teacher talk based on Flander Interaction Analysis Categories (FIAC) system. It reflects that most of the teaching learning process was devoted to asking questions and lecturing by the lecturer. The proportation of content cross in the first meeting was $65.55 \%$, in the second meeting $95.88 \%$, and in the third meeting was $97.44 \%$.

Furthermore, based on step 4 (the additional data), the most dominant characteristic or category in Speaking 2 subject class was teacher talk. It means that all of teacher talk categories appeared in each meeting. It also shows that the lecturer spent more time in the classroom than the students. The proportation of teacher talk in each meeting; the first meeting was $38.16 \%$, the second meeting was $55.11 \%$, and the third meeting was $54.83 \%$.

Although, in each meeting the lecturer dominated the talk or interaction in the classroom, the students were still active enough in the classroom interaction. The result showed that the students' participation (students' talk response and students' talk initiation) was high enough from the total teaching learning process.

Moreover, it could be said that the interaction in the Speaking 2 subject class was in three ways communication; there were interaction between the lecturer to the students, the students to the lecturer, and the students to the students. The interaction between teacher and students could be seen from the teacher's activity in asking question, giving direction, accepting feeling, praising or encouraging, accepting or using students' 
ideas, and criticizing or justifying authority. The interaction between students to the teacher could be seen from the students' activity like students' talk response and students' talk initiation. The the students to the students interaction appeared when the students had a discussion with their groups or partner.

\section{REFERENCES}

Arockiasamy. (2012). Educational technology. Retrieved on February_6, 2015. from http://www.google.com/url?sa=t\&rct=j\&q=\&e $\mathrm{src}=\mathrm{s} \&$ source $=\mathrm{web} \& \mathrm{~cd}=31 \& \mathrm{ved}=0 \mathrm{CB} 4 \mathrm{QFjA}$ AOB4\&url=http $\% 3 \mathrm{~A} \% 2 \mathrm{~F} \% 2 \mathrm{Fstxaviersbedcoll}$ ege.org\%2Fsim\%2Ftechnology_arock.pdf\&ei= T4H2VI_2KIK78gX6ioHwCg\&usg=AFQjCN FUtdF_d2omxJXq5ojJ1Bp0U51UPg.

Brown, H. D. (2001). Teaching by principles: An interactive approach to language pedagogy ( $2^{\text {nd }}$ edition). New York: Addison Wesley Longman, Inc.

Crystal, D. (2003). English as a global language (2 $2^{\text {nd }}$ ed.). Cambridge: Cambridge University Press.

Dagarin, M. (2004). Classroom interaction and communication strategies in learning English as a foreign. Ljubljana: ELOPE.

Flanders, N. A. (1970). Interaction analysis in the classroom: A manual for observers. Ann Arbor: School of Education, University of Michigan.

Rivers, W. M. (1987). Interactive language teaching: Interaction as the key to teaching language for communication. New York: Cambridge University Press. 